\title{
Nikiel i jego związki \\ Metoda oznaczania w powietrzu na stanowiskach pracy ${ }^{1}$
}

\author{
Nickel and its compounds \\ Determination in workplace air
}

\author{
mgr PAWEE WASILEWSKI \\ https://orcid.org/0000-0001-6735-4207 \\ e-mail: pawas@ciop.pl \\ Centralny Instytut Ochrony Pracy - Państwowy Instytut Badawczy \\ Central Institute for Labour Protection - National Research Institute, Warsaw, Poland
}

Numer CAS 7440-02-0

\section{Streszczenie}

Nikiel dzięki swoim właściwościom fizykochemicznym jest stosowany do wytwarzania stopów o wysokiej wytrzymałości, odpornych na korozję i temperaturę, o wysokiej rezystancji i kwasoodpornych. Nikiel w postaci drobnego proszku może wywoływać odpowiedź alergiczną w kontakcie ze skórą, udowodniono również właściwości rakotwórcze przy długotrwałym narażeniu na pył niklowy. Zgodnie z proponowaną dyrektywą Parlamentu Europejskiego nr 2020/0262 zaproponowano wartość najwyższego dopuszczalnego stężenia (NDS) w powietrzu na stanowiskach pracy dla frakcji wdychalnej $0,05 \mathrm{mg} / \mathrm{m}^{3}$, a dla frakcji respirabilnej $0,01 \mathrm{mg} / \mathrm{m}^{3}(2020 / 0262 / \mathrm{COD})$. Celem badań było opracowanie metody oznaczania niklu do oceny narażenia zawodowego w zakresie $1 / 10 \div 2$ zaproponowanych wartości NDS. Metoda polega na: pobraniu aerozolu niklu i jego związków zawartych w powietrzu na filtr, mineralizacji filtra w kwasie azotowym(V) i kwasie chlorowodorowym w podwyższonej temperaturze, a następnie oznaczeniu zawartości niklu w próbce z zastosowaniem absorpcyjnej spektrometrii atomowej (AAS) z atomizacją w płomieniu. Metoda oznaczania niklu została przedstawiona w postaci procedury analitycznej, którą zamieszczono w załączniku. Zakres tematyczny artykułu obejmuje zagadnienia zdrowia oraz bezpieczeństwa i higieny środowiska pracy będące przedmiotem badań z zakresu nauk o zdrowiu i inżynierii środowiska.

Słowa kluczowe: nikiel, substancje rakotwórcze, absorpcyjna spektrometria atomowa, narażenie zawodowe, powietrze na stanowiskach pracy, nauki o zdrowiu, inżynieria środowiska.

\footnotetext{
Abstract

Nickel due to its physicochemical properties is used to produce high strength, corrosion resistant, temperature resistant, high resistance and acid resistant alloys. Nickel in the form of fine powder can induce an allergic response when in contact with the skin, carcinogenic properties have been proven with long-term exposure to nickel dust. According to

${ }^{1}$ Opracowano na podstawie wyników V etapu programu wieloletniego „Poprawa bezpieczeństwa i warunków pracy”, finansowanego w zakresie zadań służb państwowych ze środków Ministerstwa Rozwoju, Pracy i Technologii (zadanie nr 1.SP.03 pt.: Opracowanie znowelizowanych metod oznaczania 9 szkodliwych substancji chemicznych dla potrzeb oceny środowiska pracy).

Koordynator programu: Centralny Instytut Ochrony Pracy - Państwowy Instytut Badawczy
} 
the proposed directive of the European Parliament No. 2020/0262, a value of maximum allowable concentration (MAC) in a workplace air in Poland for the inhalable fraction should be at $0.05 \mathrm{mg} / \mathrm{m}^{3}$ and for the respirable fraction at $0.01 \mathrm{mg} / \mathrm{m}^{3}$ (2020/0262/COD). The aim of this study was to develop a method for determining nickel in the range of $1 / 10 \div 2$ of the MAC. The method is based on gathering nickel aerosol and its compounds contained in the air on a filter, filter mineralization in nitric acid(V) and hydrochloric acid at elevated temperature then determination of nickel content in the sample using atomic absorption spectrometry (AAS) with flame atomization. The method for the determination of nickel is presented in the form of an analytical procedure, which is included in the appendix. This article discusses the problems of occupational safety and health, which are covered by health sciences and environmental engineering.

Keywords: nickel, carcinogens, atomic absorption spectrometry, occupational exposure, workplace air, health sciences, environmental engineering.

\section{WPROWADZENIE}

Nikiel (CAS: 7440-02-0) jest metalem przejściowym należącym do 10. grupy i 4 . okresu układu okresowego pierwiastków. Liczba atomowa niklu wynosi 26 , a jego masa atomowa 58,69 . Temperatura topnienia niklu wynosi $1453^{\circ} \mathrm{C}$, a temperatura wrzenia $2832^{\circ} \mathrm{C}$. Nikiel jako jeden z nielicznych pierwiastków jest ferromagnetykiem (ChemPył 2021; GESTIS 2021).

W przyrodzie nikiel występuje głównie wraz $\mathrm{z}$ innymi pierwiastkami $\mathrm{w}$ postaci minerałów, do najważniejszych minerałów niklu zalicza się: gersdorfit (NiAsS), chloantyt $\left(\mathrm{NiAs}_{3}\right)$, pentlandyt $\left((\mathrm{Ni}, \mathrm{Fe})_{9} \mathrm{~S}_{8}\right)$; nikiel stanowi 0,0084\% skorupy ziemskiej. Największe złoża niklu znajdują się w Kanadzie, gdzie jest wydobywany wraz z rudami miedzi. W związku z występowaniem innych metali w rudach niklu przeróbka takich rud jest utrudniona ze względu na konieczność rozdzielenia niklu od pozostałych metali. Do otrzymywania niklu o wysokiej czystości stosuje się metodę karbonylkową Monda, która polega na utworzeniu lotnego tetrakarbonylku niklu $\left(\mathrm{Ni}(\mathrm{CO})_{4}\right.$ ) poprzez działanie na rudy zawierające nikiel tlenkiem węgla $w$ temperaturze $350 \mathrm{~K}$. Otrzymany tetrakarbonylek niklu rozkłada się termicznie w temperaturze około $450 \mathrm{~K}$ do metalicznego niklu (Bielański 2005).

Nikiel jest srebrnobiałym metalem o złotawym zabarwieniu. Nie jest aktywnym metalem, dzięki czemu nie ulega działaniu powietrza ani wody, jednak w formie drobno rozdrobnionej może mieć właściwości piroforyczne. Nikiel można roztwarzać $\mathrm{w}$ rozcieńczonych kwasach, czego produktem są jony niklu i wodór. Pod działaniem stężonego kwasu azotowego(V) lub wody królewskiej nikiel ulega pasywacji. Nikiel występuje na wielu stopniach utlenienia począwszy od -I do IV, najbar- dziej rozpowszechniony jest na II stopniu utlenienia (Lee 1997).

Nikiel należy do ważnych metali technicznych, jednak jego użycie jest ograniczone ze względu na powiększający się deficyt w naturalnym środowisku. Wykazuje bardzo dobrą odporność na korozję atmosferyczną, w środowisku słonej wody i na kwasy organiczne. Nikiel jest składnikiem wielu cennych stopów, które można podzielić na: stopy konstrukcyjne, stopy oporowe, stopy odporne na korozję oraz stopy żarowytrzymałe. W związku $\mathrm{z}$ wymienionymi właściwościami nikiel wykorzystywany jest do: wyrobu drobnych monet, przewodów elektrycznych, elementów grzejnych w piecach, opornic i powłok galwanicznych. Nikiel wykazuje również silne właściwości katalityczne, głównie w reakcjach uwodorniania związków organicznych. Jako katalizatory stosuje się zredukowane związki niklu na powierzchni porowatego nośnika lub nikiel Raneya (Bielański 2005; Dobrzański 1999).

Nikiel w formie drobnego proszku przedostaje się do ludzkiego organizmu głównie drogą oddechową. Pył niklowy może być uwalniany podczas obróbki minerałów zawierających nikiel lub podczas obróbki mechanicznej stopów metali zawierających nikiel. Kontakt z niklem i jego związkami może powodować alergiczną reakcję skóry, natomiast długotrwałe narażenie może prowadzić do powstawania nowotworów (GESTIS 2021).

Zarówno nikiel, jak i proszek niklowy (średnica cząstek $<1 \mathrm{~mm}$ ) są sklasyfikowane jako: substancje rakotwórcze (kat. zagrożenia 2.), mogące powodować uszkodzenie narządów poprzez długotrwałe lub powtarzane narażenie (kat. zagrożenia 1.) oraz mogące powodować reakcję alergiczną skóry 
(kat. zagrożenia 1.). Dodatkowo proszek niklowy sklasyfikowano jako działający szkodliwie na organizmy wodne, powodując długotrwałe skutki (kat. zagrożenia 3.). Substancjom tym przypisano również zwroty wskazujące rodzaj zagrożenia: H351: podejrzewa się, że powoduje raka, H372: powoduje uszkodzenie narządów, H317: może powodować reakcję alergiczną skóry. Proszek niklowy dodatkowo ma zwrot wskazujący zagrożenie: H412: działający szkodliwie na organizmy wodne, powodując długotrwałe skutki (WE 1272/2008).

W rozporządzeniu Komisji Europejskiej (WE 1272/2008) znajduje się ponad 100 związków zawierających nikiel. Wszystkie zostały sklasyfikowane jako substancje: rakotwórcze, mogące powodować uszkodzenie narządów poprzez długotrwałe lub powtarzane narażenie oraz mogące powodować reakcję alergiczną skóry. Dodatkowo większość sklasyfikowano jako substancje działające szkodliwie na organizmy wodne.

Obecnie wartość normatywu higienicznego najwyższego dopuszczalnego stężenia (NDS) dla związków niklu (z wyjątkiem tetrakarbonylku niklu) w powietrzu na stanowiskach pracy wynosi $0,25 \mathrm{mg} / \mathrm{m}^{3}$. Wartość najwyższego dopuszczalnego stężenia chwilowego (NDSCh) nie została ustalona (Rozporządzenie MRPiPS 2018).

Do oznaczania niklu i jego związków Amerykański Narodowy Instytut Bezpieczeństwa i Higieny Pracy (NIOSH) zaleca stosowanie metody spektrometrii emisyjnej ze wzbudzeniem $\mathrm{w}$ plazmie sprzężonej indukcyjnie (ICP-OES).
Wykorzystując tę metodę, można uzyskać niską granicę wykrywalności niklu na poziomie $0,8 \mu \mathrm{g} / \mathrm{l}$ (NIOSH 2003a; 2003b) oraz $12 \mu \mathrm{g} / \mathrm{l}$ (NIOSH 2003c) w zależności od sposobu przygotowania próbki. Do mineralizacji z użyciem płyty grzejnej wykorzystuje się kwas nadchlorowy z kwasem azotowym(V) lub wodę królewską, a dla metody "hot block” filtr mineralizuje się z użyciem kwasu solnego z kwasem azotowym(V).

Do oznaczania niklu i jego związków można również wykorzystać metodę absorpcyjnej spektrometrii atomowej (AAS) dzięki zastosowaniu płomienia acetylen-powietrze, w metodzie tej granica wykrywalności wynosi $2 \mu \mathrm{g} / \mathrm{l}$ (OSHA 1985).

Celem prac badawczych była nowelizacja normy PN-Z-04502 dotyczącej oznaczania niklu i jego związków na stanowiskach pracy metodą absorpcyjnej spektrometrii atomowej (AAS), w której to normie oznaczalność wynosiła $0,014 \mathrm{mg} / \mathrm{m}^{3}$. Od 18 stycznia 2025 roku będzie obowiązywać najwyższe dopuszczalnie stężenie $0,01 \mathrm{mg} / \mathrm{m}^{3}$ dla frakcji respirabilnej i $0,05 \mathrm{mg} / \mathrm{m}^{3}$ dla frakcji wdychalnej (2020/0262/COD).

Celem prac badawczych było opracowanie metody oznaczania niklu w zakresie $1 / 10 \div 2$ wartości NDS, co odpowiada stężeniom $0,001 \div 0,02 \mathrm{mg} /$ $\mathrm{m}^{3}$, oraz wyznaczenie parametrów walidacyjnych.

Zakres tematyczny artykułu obejmuje zagadnienia zdrowia oraz bezpieczeństwa i higieny środowiska pracy będące przedmiotem badań z zakresu nauk o zdrowiu i inżynierii środowiska.

\section{CZĘŚĆ DOŚWIADCZALNA}

\section{Aparatura i sprzęt}

Do oznaczania niklu i jego związków z wyjątkiem tetrakarbonylku niklu zastosowano spektrofotometr do absorpcji atomowej firmy Thermo Electron SOLAAR M, wyposażony w lampę z katodą wnękową (HDL) do oznaczania niklu, $z$ deuterową korekcją tła. Atomizacje przeprowadzono w płomieniu acetylen-powietrze.

Do sporządzania roztworów stosowano pipety automatyczne (Brand, Niemcy), do analiz stosowano wysokiej jakości wodę demineralizowaną otrzymaną z systemu Milli-Q (Millipore, USA). Filtry membranowe użyte w analizie były wykona- ne z mieszaniny estrów celulozowych (SKC, USA) o średnicy porów $0,45 \mu \mathrm{m}$. Do mineralizacji użyto płyty grzejnej (IKA, Japonia).

\section{Odczynniki i roztwory}

Podczas badania stosowano następujące odczynniki i roztwory o czystości przynajmniej cz.d.a.: kwas azotowy(V) 65-procentowy o gęstości 1,42 g/ml (Merck, USA), kwas chlorowodorowy 30-procentowy o gęstości 1,15 g/ml (Merck, USA), roztwór wzorcowy niklu o stężeniu $1 \mathrm{mg} / \mathrm{ml}$ do absorpcji atomowej (Sigma-Aldrich, USA). 


\section{WYNIKI BADAŃ I ICH OMÓWIENIE}

\section{Parametry oznaczania}

W zastosowanej technice metody AAS atomizacja próbki zachodzi w płomieniu powietrze-acetylen, płomień ten znajduje się na drodze wiązki promieniowania charakterystycznego dla analizowanego metalu. Podczas oznaczania niklu wykorzystuje się promieniowanie przy długości fali $232,0 \mathrm{~nm}$. Wykonując analizę, wykorzystano parametry oznaczania wyznaczone eksperymentalnie przez optymalizację dla próbki sporządzonej do analizy. Zoptymalizowano: natężenie prądu lampy, wysokość nad palnikiem i przepływ acetylenu.

Najlepszą czułość i precyzję oznaczeń uzyskano przy zastosowaniu następujących parametrów:

- długość fali - 232,0 nm

- typ lampy - lampa z katodą wnękową HDL

- szerokość szczeliny - 0,2 nm

- natężenie prądu lampy - $15 \mathrm{~mA}$

- rodzaj płomienia - acetylen-powietrze

- przepływ paliwa (acetylen) - 0,9 1/min

- wysokość nad palnikiem - 7,0 mm.

\section{Krzywa wzorcowa i precyzja}

Do sporządzenia krzywej kalibracyjnej wykorzystano sześć roztworów wzorcowych roboczych o stężeniach niklu: 0,$30 ; 0,60 ; 1,00 ; 3,00 ; 5,00$ i $8,50 \mu \mathrm{g} / \mathrm{ml}$, oraz próbkę zerową sporządzoną tak samo jak roztwory wzorcowe, lecz bez dodatku niklu. Pomiary były prowadzone przy podanych parametrach. Do zerowania spektrometru wykorzystywano kwas azotowy(V) o stężeniu 0,1 mol/l. Przy wykonywaniu analizy do każdego odczytu dla danej próbki uśredniano trzy odczyty absorbancji. Sporządzono trzy serie roztworów do krzywej kalibracyjnej, których wyniki uśredniono; otrzymano nieliniową funkcję o wzorze: $y=0,0017 x^{2}+0,0679 x-0,0017$, o współczynniku korelacji $R^{2}=0,9998$ (ryc. 1.).

W celu wyznaczenia precyzji pomiarów przygotowano po osiem roztworów modelowych $(n=8)$ na trzech następujących poziomach: 0,30; 3,00 i $8,50 \mu \mathrm{g} / \mathrm{ml}$ stężenia niklu. Każdy pomiar przeprowadzono $\mathrm{w}$ takich samych warunkach jak wykonywanie oznaczeń kalibracyjnych. Wyniki badań precyzji przedstawiono w tabeli 1. Współczynnik zmienności dla kolejnych poziomów stężenia wynosi odpowiednio: 2,63 ; 0,86 i $0,28 \%$.

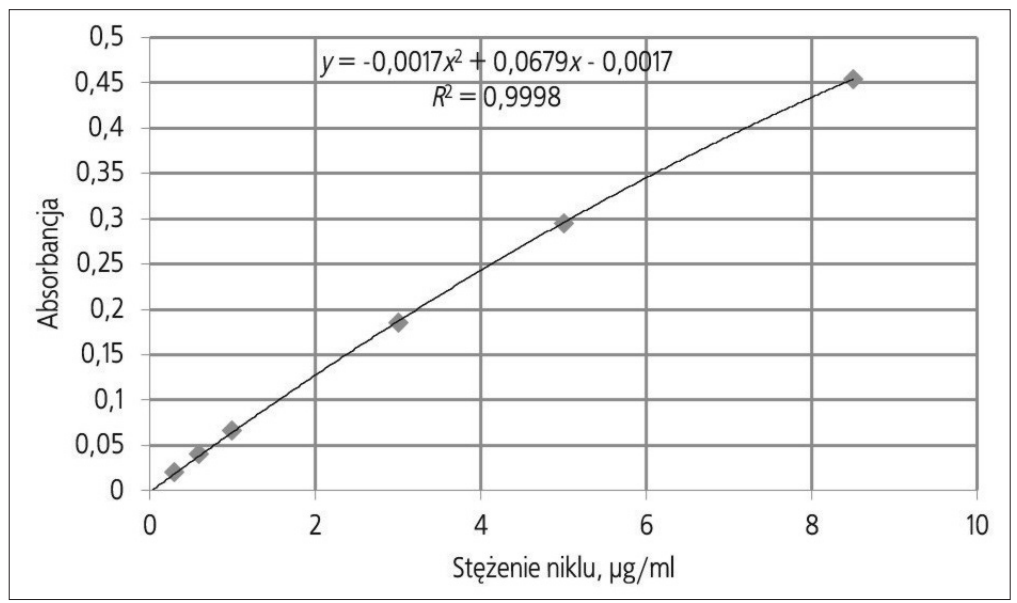

Ryc. 1. Krzywa wzorcowa oznaczania niklu metodą F-AAS, przy długości fali 232,0 nm, z atomizacją w płomieniu acetylen-powietrze Fig. 1. Calibration curve for determining nickel with F-AAS method, $232.0 \mathrm{~nm}$, with acetylene-air flame

Tabela 1. Precyzja oznaczeń kalibracyjnych niklu metodą F-AAS, przy długości fali 232,0 nm, z atomizacją w płomieniu acetylen-powietrze Table 1. Precision of calibration determinations of nickel with F-AAS method, $232.0 \mathrm{~nm}$, with acetylene-air flame

\begin{tabular}{|l|c|c|c|}
\hline \multirow{2}{*}{ Badany parametr } & \multicolumn{3}{|c|}{ Stężenie niklu, $\mathrm{\mu g} / \mathrm{ml}$} \\
\cline { 2 - 4 } & 0,3 & 3 & 8,5 \\
\hline Średnie zmierzone stężenie $(n=8)$ & 0,29 & 3,06 & 8,53 \\
Odchylenie standardowe & 0,01 & 0,03 & 0,02 \\
Współczynnik zmienności, \% & 2,63 & 0,86 & 0,28 \\
\hline
\end{tabular}




\section{Badanie skuteczności mineralizacji}

Mineralizację filtrów MCE przeprowadzono z użyciem stężonych kwasów: azotowego $(\mathrm{V})$ i chlorowodorowego (OSHA 1985). Do zbadania współczynnika odzysku przeprowadzono pomiary na czterech różnych poziomach stężeń niklu (sześć próbek na każdy poziom). W celu przeprowadzenia mineralizacji filtrów $\mathrm{w}$ sześciu zlewkach umieszczono filtry MCE, na które naniesiono dla każdego poziomu po: 15, 50, 100 i $200 \mu \mathrm{l}$ wzorcowego roztworu niklu o stężeniu $1 \mathrm{mg} / \mathrm{ml}$. Po wyschnięciu filtrów dodawano do nich po $2 \mathrm{ml}$ stężonego kwasu azotowego(V) i ogrzewano na płycie grzejnej w temperaturze około $150^{\circ} \mathrm{C}$ aż do odparowania kwasu prawie do sucha; proces był prowadzony w dygestorium. Proces powtarzano trzykrotnie, dodatkowo do ostatniej porcji kwasu azotowego(V) dodano kroplę stężonego kwasu chlorowodorowego i odparowano prawie do sucha. Po wystudzeniu roztworu dodano do niego $5 \mathrm{ml} \mathrm{kwasu}$ azotowego(V) o stężeniu $0,1 \mathrm{~mol} / \mathrm{ml}$ i wymieszano, roztwór przeniesiono ilościowo do kolby miarowej o pojemności $25 \mathrm{ml}$. Do kolby dodano $5 \mathrm{ml}$ kwasu azotowego(V) o stężeniu $1 \mathrm{~mol} / \mathrm{l}$, a następnie uzupełniono do kreski kwasem azotowym(V) o stężeniu $0,1 \mathrm{~mol} / \mathrm{l}$. Uzyskano roztwory o następujących stężeniach niklu: 0,$60 ; 2,00 ; 4,00$ i $8,00 \mu \mathrm{g} / \mathrm{ml}$. Równolegle należy mineralizować czysty filtr, bez naniesionego roztworu niklu - ślepą próbę, której wynik będzie odejmowany od wyniku oznaczenia.

Dla każdego poziomu stężeń przygotowano również po trzy roztwory porównawcze. Do przygotowania roztworów porównawczych należy do kolby o pojemności $25 \mathrm{ml}$ dodać taką samą objętość roztworu wzorcowego niklu, jaką nanoszono na filtry, następnie dodać $5 \mathrm{ml} \mathrm{kwasu} \mathrm{azotowego(V)}$ o stężeniu $1 \mathrm{~mol} / \mathrm{l}$ i uzupełnić do kreski kwasem azotowym(V) o stężeniu $0,1 \mathrm{~mol} / \mathrm{l}$.

Do wyznaczenia skuteczności mineralizacji należy analizować próbki metodą absorpcyjnej spektrometrii atomowej przy użyciu takich samych parametrów jak przy sporządzaniu krzywej wzorcowej. Dla otrzymanych roztworów na czterech poziomach stężeń wyznaczono odzysk: 0,$96 ; 0,98$; 0,99 i 0,99 oraz współczynnik zmienności odzysku: 2,10;1,86; 1,69 i 0,21\%; średni współczynnik odzysku wyniósł 0,98 . W tabeli 2. zamieszczono dane badania skuteczności mineralizacji.

Tabela 2. Wyniki badania odzysku związków niklu z filtra membranowego

Table 2. Results of the studies on the recovery of nickel compounds from a membrane filter

\begin{tabular}{|c|c|c|c|c|c|c|c|}
\hline Numer próbki & $\begin{array}{l}\text { Oznaczone } \\
\text { stężenie, } \\
\text { wartość } \\
\text { średnia dla } \\
n=3 \\
\mu \mathrm{g} / \mathrm{ml}\end{array}$ & $\begin{array}{l}\text { Stężenie } \\
\text { średnie, } \\
\mu \mathrm{g} / \mathrm{ml}\end{array}$ & $\begin{array}{l}\text { Współczynnik } \\
\text { odzysku }\end{array}$ & Numer próbki & $\begin{array}{l}\text { Oznaczone } \\
\text { stężenie, } \\
\text { wartość } \\
\text { średnia dla } \\
n=3, \\
\mu \mathrm{g} / \mathrm{ml}\end{array}$ & $\begin{array}{l}\text { Stężenie } \\
\text { średnie, } \\
\mu \mathrm{g} / \mathrm{ml}\end{array}$ & $\begin{array}{l}\text { Współczynnik } \\
\text { odzysku }\end{array}$ \\
\hline $1 \mathrm{~A}$ & 0,61 & \multirow{3}{*}{0,61} & & $2 \mathrm{~A}$ & 2,00 & \multirow{3}{*}{2,01} & \\
\hline 1B & 0,62 & & & $2 \mathrm{~B}$ & 2,05 & & \\
\hline $1 \mathrm{C}$ & 0,61 & & & $2 C$ & 1,99 & & \\
\hline $1 \mathrm{a}$ & 0,58 & \multirow{6}{*}{0,59} & 0,95 & $2 a$ & 1,96 & \multirow{6}{*}{1,97} & 0,97 \\
\hline $1 \mathrm{~b}$ & 0,61 & & 1,00 & $2 b$ & 1,96 & & 0,98 \\
\hline $1 c$ & 0,58 & & 0,95 & $2 c$ & 1,97 & & 0,98 \\
\hline $1 d$ & 0,60 & & 0,97 & $2 d$ & 2,05 & & 1,02 \\
\hline le & 0,58 & & 0,95 & $2 e$ & 1,96 & & 0,97 \\
\hline $1 f$ & 0,59 & & 0,96 & $2 f$ & 1,95 & & 0,97 \\
\hline \multicolumn{3}{|c|}{$\begin{array}{l}\text { Średnia wartość } \\
\text { współczynnika odzysku }\end{array}$} & 0,96 & \multicolumn{3}{|c|}{$\begin{array}{l}\text { Średnia wartość } \\
\text { współczynnika odzysku }\end{array}$} & 0,98 \\
\hline \multicolumn{3}{|c|}{ Odchylenie standardowe, SD } & 0,020 & \multicolumn{3}{|c|}{ Odchylenie standardowe, SD } & 0,018 \\
\hline \multicolumn{3}{|c|}{$\begin{array}{l}\text { Współczynnik zmienności } \\
\text { współczynnika odzysku, CV, \% }\end{array}$} & 2,10 & \multicolumn{3}{|c|}{$\begin{array}{l}\text { Współczynnik zmienności } \\
\text { współczynnika odzysku, CV, \% }\end{array}$} & 1,86 \\
\hline
\end{tabular}


cd. tab. 2.

\begin{tabular}{|c|c|c|c|c|c|c|c|}
\hline Numer próbki & $\begin{array}{l}\text { Oznaczone } \\
\text { stężenie, } \\
\text { wartość } \\
\text { średnia dla } \\
n=3 \\
\mu \mathrm{g} / \mathrm{ml}\end{array}$ & $\begin{array}{l}\text { Stężenie } \\
\text { średnie, } \\
\mu \mathrm{g} / \mathrm{ml}\end{array}$ & $\begin{array}{l}\text { Współczynnik } \\
\text { odzysku }\end{array}$ & Numer próbki & $\begin{array}{l}\text { Oznaczone } \\
\text { stężenie, } \\
\text { wartość } \\
\text { średnia dla } \\
n=3 \\
\mu \mathrm{g} / \mathrm{ml}\end{array}$ & $\begin{array}{l}\text { Stężenie } \\
\text { średnie, } \\
\mu \mathrm{g} / \mathrm{ml}\end{array}$ & $\begin{array}{l}\text { Współczynnik } \\
\text { odzysku }\end{array}$ \\
\hline $3 \mathrm{~A}$ & 3,99 & \multirow{3}{*}{3,97} & & $4 \mathrm{~A}$ & 8,06 & \multirow{3}{*}{8,05} & \\
\hline $3 B$ & 4,04 & & & $4 \mathrm{~B}$ & 8,04 & & \\
\hline $3 C$ & 3,88 & & & $4 C$ & 8,05 & & \\
\hline $3 a$ & 3,98 & \multirow{6}{*}{3,94} & 1,00 & $4 a$ & 8,02 & \multirow{6}{*}{8,01} & 1,00 \\
\hline $3 b$ & 3,93 & & 0,99 & $4 b$ & 8,00 & & 0,99 \\
\hline $3 c$ & 3,88 & & 0,98 & $4 c$ & 8,02 & & 1,00 \\
\hline $3 d$ & 4,05 & & 1,02 & $4 d$ & 7,98 & & 0,99 \\
\hline $3 e$ & 3,92 & & 0,99 & $4 e$ & 8,02 & & 1,00 \\
\hline $3 f$ & 3,87 & & 0,98 & $4 f$ & 8,03 & & 1,00 \\
\hline \multicolumn{3}{|c|}{$\begin{array}{l}\text { Średnia wartość } \\
\text { współczynnika odzysku }\end{array}$} & 0,99 & \multicolumn{3}{|c|}{$\begin{array}{l}\text { Średnia wartość } \\
\text { współczynnika odzysku }\end{array}$} & 0,99 \\
\hline \multicolumn{3}{|c|}{ Odchylenie standardowe, SD } & 0,017 & \multicolumn{3}{|c|}{ Odchylenie standardowe, SD } & 0,002 \\
\hline \multicolumn{3}{|c|}{$\begin{array}{l}\text { Współczynnik zmienności } \\
\text { współczynnika odzysku, CV, \% }\end{array}$} & 1,69 & \multicolumn{3}{|c|}{$\begin{array}{l}\text { Współczynnik zmienności } \\
\text { współczynnika odzysku, CV, \% }\end{array}$} & 0,21 \\
\hline
\end{tabular}

\section{Wpływ substancji współtowarzyszących}

Przeprowadzono badania w celu sprawdzenia, czy obecność substancji współwystępujących ma wpływ na wynik oznaczania niklu w przyjętych warunkach. Badania przeprowadzono dla metali, które mogą występować wraz z niklem $\mathrm{w}$ procesach technologicznych. W tym celu przygotowano roztwory próbek oprócz niklu zawierające w nadmiarze inne pierwiastki.

W toku badań ustalono, że nadmiar pierwiastków: $\mathrm{Mn}, \mathrm{Cu}, \mathrm{Fe}$ i Co w stężeniach do $50 \mu \mathrm{g} / \mathrm{ml}$ nie wpływa na wynik oznaczania $\mathrm{z}$ wykorzystaniem opisanej metody.

\section{Wyznaczanie granicy oznaczania}

Granicę oznaczania ilościowego (LOQ) wyznaczono poprzez wykreślenie zależności współczynnika zmienności CV od absorbancji niklu, a następnie na podstawie metody graficznej określono LOQ na poziomie 5\% współczynnika zmienności (ryc. 2.), (Konieczka 2004).
Do wyznaczenie granicy oznaczania wykonano próbki o stężeniach niklu kolejno: 0,$04 ; 0,06 ; 0,10$; 0,20 i $0,30 \mu \mathrm{g} / \mathrm{ml}$. Dla każdego poziomu stężeń wykonano sześć pomiarów absorbancji. Wyznaczone współczynniki zmienności wynosiły: 76,57; 25,13; 8,$78 ; 2,93$ i $2,38 \%$.

Granicę oznaczalności (LOQ) wyznaczono przy stężeniu $0,16 \mu \mathrm{g} / \mathrm{ml}$. Do obliczenia granicy wykrywalności (LOD) wykorzystano wzór: LOD = $3 \cdot \mathrm{LOQ}$, wartość ta wyniosła $0,054 \mu \mathrm{g} / \mathrm{ml}$.

\section{Walidacja metody}

Walidację metody przeprowadzono zgodnie z wymaganiami normy europejskiej PN-EN 482. Oznaczanie niklu zostało przeprowadzone $\mathrm{z}$ zastosowaniem spektrofotometru absorpcji atomowej firmy Thermo Electron Corporation, model SOLAAR M. Zastosowano lampę z katodą wnękową do oznaczania niklu firmy Thermo Electron Corporation. Uzyskane dane walidacyjne przedstawiono w tabeli 3. 


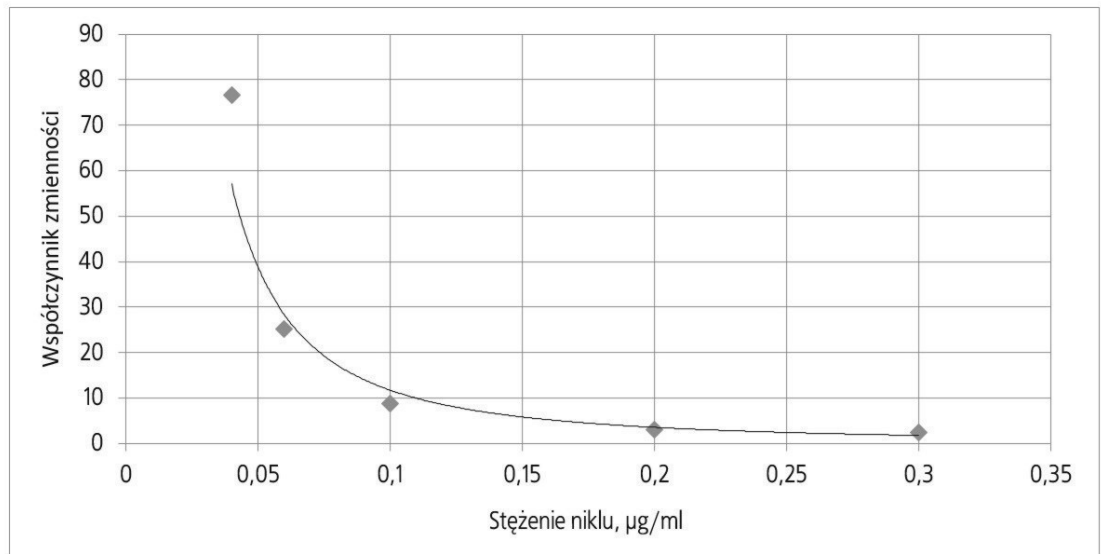

Ryc. 2. Wykres zależności współczynnika zmienności sygnału od stężenia niklu. Metoda F-AAS, długość fali 232,0 nm, z atomizacją w płomieniu acetylen-powietrze

Fig. 2. Dependence of coefficient of variation of the signal on nickel concentration with F-AAS method, $232.0 \mathrm{~nm}$, with acetylene-air flame

Tabela 3. Parametry walidacyjne metody oznaczania niklu i jego związków

Table 3. Validation parameters of the method for determining nickel and nickel compounds

\begin{tabular}{|l|l|}
\hline Parametr & Wartość \\
\hline Zakres pomiarowy metody & $0,001 \div 0,1 \mathrm{mg} / \mathrm{m}^{3}$ \\
Ilość pobranego powietrza & $\begin{array}{l}\text { frakcja respirabilna: } 3360 \mathrm{I} \\
\text { frakcja wdychalna: } 840 \text { I }\end{array}$ \\
Zakres krzywej wzorcowej & $0,3 \div 8,5 \mu \mathrm{g} / \mathrm{ml}$ \\
Granica wykrywalności & $0,054 \mu \mathrm{g} / \mathrm{ml}$ \\
Granica oznaczalności & $0,16 \mu \mathrm{g} / \mathrm{ml}$ \\
Całkowita precyzja badania & $5,25 \%$ \\
Względna niepewność całkowita & $11,48 \%$ \\
Niepewność rozszerzona & $22,96 \%$ \\
\hline
\end{tabular}

\section{PODSUMOWANIE}

Znowelizowano normę PN-Z-04502:2019-10 pod względem oznaczania niklu i jego związków (z wyjątkiem tetrakarbonylku niklu) w powietrzu na stanowiskach pracy metodą absorbacyjnej spektrofotometrii atomowej. Zakres metody oznaczania wynosi dla frakcji respirabilnej: $0,001 \div$ $0,02 \mathrm{mg} / \mathrm{m}^{3}$ i dla frakcji wdychalnej: $0,005 \div$ $0,1 \mathrm{mg} / \mathrm{m}^{3}$, co odpowiada zakresowi $1 / 10 \div 2 \mathrm{za}-$ proponowanej wartości NDS dla frakcji wdychalnej i respirabilnej. Zmiany wartości NDS dla niklu i jego związków zostaną wprowadzone 28 stycznia 2025 roku (2020/0262/COD).

Metoda polega na zatrzymaniu na filtrze MCE aerozolu niklu i jego związków obecnych na stano- wiskach pracy. Po mineralizacji filtra oznacza się ilościowo nikiel z użyciem absorpcyjnej spektrometrii atomowej $\mathrm{z}$ atomizacją $\mathrm{w}$ płomieniu acetylen-powietrze przy długości fali 232,0 nm.

Metoda spełnia wymagania zawarte $\mathrm{w}$ normie PN-EN 482 i ma dobrą precyzję oznaczeń. Metoda może być wykorzystywana przez laboratoria higieny pracy przy oznaczaniu zawartości niklu i jego związków w powietrzu.

Opracowaną metodę oznaczania niklu i jego związków w formie procedury analitycznej zamieszczono w załączniku. 


\section{PIŚMIENNICTWO}

Bielański A. (2005). Podstawy chemii nieorganicznej 2. Warszawa, Wydawnictwo Naukowe PWN.

ChemPył (2021). Baza wiedzy o zagrożeniach chemicznych i pyłowych. Warszawa, CIOP-PIB.

Dobrzański L.A. (1999). Metaloznawstwo z podstawami nauki o materiałach. Warszawa, Wydawnictwa Naukowo-Techniczne.

Dyrektywa Parlamentu Europejskiego i Rady nr 2020/0262 zmieniająca dyrektywę 2004/37/WE w sprawie ochrony pracowników przed zagrożeniem dotyczącym narażenia na działanie czynników rakotwórczych lub mutagenów podczas pracy $(2020 / 0262 / C O D)$.

GESTIS (2021). GESTIS Substance database. Germany, Sankt Augustin, BG Institute for Occupational Safety and Health.

Konieczka P. (2004). Ocena i kontrola jakości wyników analitycznych. Gdańsk, CEEAM Wydział Chemiczny, Politechnika Gdańska.

Lee J.D. (1997). Zwięzła chemia nieorganiczna. Warszawa, Wydawnictwo Naukowe PWN.

National Institute for Occupational Safety and Health (NIOSH), (2003a). Elements by ICP (Nitric/Perchloric Acid Ashing) - Method 7300. NIOSH Manual of Analytical Methods (NMAM), Fourth Edition.

National Institute for Occupational Safety and Health (NIOSH), (2003b). Elements by ICP (Aqua Regia Ashing) - Method 7301. NIOSH Manual of Analytical Methods (NMAM), Fourth Edition.

National Institute for Occupational Safety and Health (NIOSH), (2003c). Elements by ICP (Hot Block/HCl/ $\mathrm{HNO}_{3}$ Digestion) - Method 7303. NIOSH Manual of Analytical Methods (NMAM), Fourth Edition.
Occupational Safety and Health Administration (OSHA), (1985). Method No. ID-121. Metal and metalloid particulates in workplace atmospheres (atomic absorption), (sampling and analytical method, revised February 2002). Organic Methods Evaluation Branch, OSHA Analytical Laboratory, Salt Lake City, Utah.

PN-Z-04008-7:2002/Az1:2004 Ochrona czystości powietrza Pobieranie próbek - Zasady pobierania próbek powietrza na stanowiskach pracy i interpretacji wyników.

PN-Z-04502:2019-10 Ochrona czystości powietrza - Oznaczanie niklu i jego związków na stanowiskach pracy metodą płomieniowej absorpcyjnej spektrometrii atomowej.

Rozporządzenie Komisji (UE) 2018/669 z dnia 16 kwietnia 2018 r. zmieniające, w celu dostosowania do postępu naukowo-technicznego, rozporządzenie Parlamentu Europejskiego i Rady (WE) nr 1272/2008 w sprawie klasyfikacji, oznakowania i pakowania substancji i mieszanin. Dz. Urz. UE z dnia 4.05.2018 r. (L 115/1) [Commission Regulation (EU) 2018/669 of 16 April 2018 amending, for the purposes of its adaptation to technical and scientific progress, Regulation (EC) No 1272/2008 of the European Parliament and of the Council on classification, labelling and packaging of substances and mixtures. OJEU L115/1].

Rozporządzenie Ministra Rodziny, Pracy i Polityki Społecznej z dnia 12 czerwca 2018 r. w sprawie najwyższych dopuszczalnych stężeń i natężeń czynników szkodliwych dla zdrowia w środowisku pracy. DzU 2018, poz. 1286 ze zm. 


\section{PROCEDURA ANALITYCZNA OZNACZANIA NIKLU I JEGO ZWIAZZKÓW W POWIETRZU NA STANOWISKACH PRACY METODAC PŁOMIENIOWEJ ABSORPCYJNEJ SPEKTROMETRII ATOMOWEJ}

\section{Zakres procedury}

$\mathrm{W}$ niniejszej procedurze przedstawiono metodę oznaczania niklu (CAS: 7440-02-0) i jego związków w powietrzu na stanowiskach pracy z zastosowaniem płomieniowej absorpcyjnej spektrometrii atomowej. Metodę stosuje się podczas kontroli warunków sanitarnohigienicznych.

Najmniejsze stężenie niklu i jego związków w przeliczeniu na nikiel, jakie można oznaczyć w warunkach pobierania próbek powietrza i wykonania oznaczenia opisywanych $\mathrm{w}$ procedurze, wynosi $0,001 \mathrm{mg} / \mathrm{m}^{3}$ (dla próbki powietrza o objętości $3360 \mathrm{l}$ ) oraz $0,005 \mathrm{mg} / \mathrm{m}^{3}$ (dla próbki powietrza o objętości 840 l).

\section{Powołania normatywne}

PN-Z-04008-7 Ochrona czystości powietrza Pobieranie próbek - Zasady pobierania próbek powietrza $\mathrm{w}$ środowisku pracy $\mathrm{i}$ interpretacji wyników.

PN-C-84905:1998 Gazy techniczne - Acetylen rozpuszczony.

\section{Zasada metody}

Metoda polega na zatrzymaniu aerozolu niklu i jego związków na filtrze $\mathrm{z}$ mieszaniny estrów celulozy (MCE). Filtr mineralizuje się $\mathrm{w}$ stężonym kwasie azotowym(V) i kropli stężonego kwasu chlorowodorowego, a następnie sporządza roztwór $\mathrm{w}$ rozcieńczonym kwasie azotowym $(\mathrm{V})$. Nikiel i jego związki oznacza się w tym roztworze jako nikiel metodą płomieniowej absorpcyjnej spektrometrii atomowej.

\section{Postanowienia ogólne}

4.1. Dokładność ważenia

O ile nie zaznaczono inaczej, substancje stosowane $\mathrm{w}$ analizie należy ważyć $\mathrm{z}$ dokładnością do $0,0002 \mathrm{~g}$.

\subsection{Czystość szkła}

W analizie używano wyłącznie naczyń laboratoryjnych ze szkła borowo-krzemowego lub z polietylenu. Naczynia należy myć kolejno roztworem kwasu azotowego(V) o stężeniu $1 \mathrm{~mol} / \mathrm{l}$ i wodą destylowaną, a następnie kilkukrotnie płukać wodą dwukrotnie destylowaną lub dejonizowaną.

4.3. Postępowanie z substancjami niebezpiecznymi

Czynności, podczas których używa się rozpuszczalników organicznych, należy wykonywać z użyciem środków ochrony indywidualnej pod sprawnie działającym wyciągiem laboratoryjnym.

Pozostałe po analizie roztwory odczynników i wzorców należy gromadzić w przeznaczonych do tego celu pojemnikach i przekazywać do utylizacji w uprawnionych instytucjach.

\section{Odczynniki i roztwory}

Należy stosować wodę dwukrotnie destylowaną lub dejonizowaną, zwaną $\mathrm{w}$ dalszej treści procedury wodą.

Podczas analizy, jeśli nie ma innych wymagań, należy stosować substancje o stopniu czystości co najmniej cz.d.a.

5.1. Acetylen rozpuszczony, acetylen klasy czystości A wg PN-C-84905:1998

5.2. Kwas azotowy $(\mathrm{V})$, stężony, o stężeniu $65 \%$, o gęstości $1,42 \mathrm{~g} / \mathrm{ml}$

5.3. Kwas chlorowodorowy, stężony, o stężeniu $30 \%$, o gęstości $1,15 \mathrm{~g} / \mathrm{ml}$

5.4. Kwas azotowy $(\mathrm{V})$, roztwór o stężeniu $0,1 \mathrm{~mol} / 1$

5.5. Kwas azotowy $(\mathrm{V})$, roztwór o stężeniu $1 \mathrm{~mol} / \mathrm{l}$

5.6. Roztwór wzorcowy niklu, o stężeniu $10 \mathrm{mg} / \mathrm{ml}$ do absorpcji atomowej

5.7. Roztwór wzorcowy pośredni niklu, o stężeniu $50 \mu \mathrm{l} / \mathrm{ml}$

Do kolby pomiarowej o pojemności $25 \mathrm{ml}$ dodać $1,25 \mathrm{ml}$ roztworu wzorcowego o stężeniu $1 \mathrm{mg} / \mathrm{ml}$ wg punktu 5.6., a następnie uzupełnić do kreski kwasem azotowym(V) o stężeniu $0,1 \mathrm{~mol} / \mathrm{l}$. 


\section{Aparatura i przyrządy}

\subsection{Aspirator}

Aspirator umożliwiający pobieranie powietrza ze stałym przepływem $2 \mathrm{l} / \mathrm{min}$ dla frakcji wdychalnej oraz $8 \mathrm{l} / \mathrm{min}$ dla frakcji respirabilnej.

6.2. Pipety i mikropipety do sporządzania roztworów

6.3. Filtry z mieszaniny estrów celulozy (MCE) o średnicy porów $0,23 \mu \mathrm{m}$

6.4. Spektrometr

Spektrometr do absorpcji atomowej przystosowany do pracy $\mathrm{z}$ płomieniem powietrze-acetylen, wyposażony w lampę z katodą wnękową do oznaczania niklu.

\section{Pobieranie próbek powietrza}

Próbki powietrza należy pobierać wg normy PN-Z-04008-07. W miejscu pobierania próbek przez próbnik z filtrami MCE wg punktu 6.3. przepuścić badane powietrze ze stałym strumieniem objętości nie większym niż 8 l/min.

\section{Warunki pracy spektrometru}

Spektrofotometr do absorpcji atomowej przystosowany do pracy $\mathrm{z}$ płomieniem powietrze-acetylen, wyposażony w lampę z katodą wnękową HDL do oznaczania niklu.

Aby zapewnić wymaganą czułość i precyzję spektrofotometru podczas oznaczania niklu, należy przyjąć następujące warunki pracy:

- długość fali - 232,0 nm

- typ lampy - lampa z katodą wnękową HDL

- szerokość szczeliny - 0,2 nm

- natężenie prądu lampy - $15 \mathrm{~mA}$

- rodzaj płomienia - acetylen-powietrze

- przepływ paliwa (acetylen) - 0,9 1/min

- wysokość nad palnikiem - 7,0 mm.

\section{Przygotowanie roztworów wzorcowych i sporządzanie krzywej wzorcowej}

Roztwory niklu o stężeniach w mikrogramach na mililitr: 0,$30 ; 0,60 ; 1,00 ; 3,00 ; 5,00$ i 8,50 . Do sześciu kolb pomiarowych o pojemności $25 \mathrm{ml}$ odmierzyć następujące objętości roztworu wzorcowego pośredniego niklu wg punktu 5.7. w mililitrach: 0,$150 ; 0,300 ; 0,500 ; 1,500 ; 2,500$ i 4,250, do każdej kolby dodać $5 \mathrm{ml}$ kwasu azotowego(V) o stężeniu
$1 \mathrm{~mol} / \mathrm{l} \mathrm{wg}$ punktu 5.5., a następnie uzupełnić do kreski roztworem kwasu azotowego(V) o stężeniu $0,1 \mathrm{~mol} / \mathrm{l} \mathrm{wg}$ punktu 5.4. i dokładnie wymieszać. $\mathrm{W}$ kolejnej kolbie o pojemności $25 \mathrm{ml}$ przygotować roztwór próbki zerowej przez odmierzenie $5 \mathrm{ml} \mathrm{kwasu} \mathrm{azotowego(V)} \mathrm{wg} \mathrm{punktu} \mathrm{5.5.} \mathrm{i} \mathrm{uzupeł-}$ nienie do kreski roztworem kwasu azotowego(V) o stężeniu $0,1 \mathrm{~mol} / \mathrm{l}$ wg punktu 5.4.

Krzywą wzorcową sporządzić, korzystając z funkcji wzorcowania oprogramowania przeznaczonego dla spektrometru, zgodnie $\mathrm{z}$ instrukcją użytkowania.

Krzywą wzorcową należy sporządzić bezpośrednio przed każdym pomiarem.

\section{Wyznaczanie współczynnika odzysku}

W celu wyznaczenia wydajności mineralizacji należy nanieść po $100 \mu \mathrm{l}$ roztworu wzorcowego niklu wg punktu 5.6. na sześć filtrów wg punktu 6.3. umieszczonych w zlewkach i pozostawić do wyschnięcia. Następnie do każdej zlewki dodać po $2 \mathrm{ml}$ kwasu azotowego(V) wg punktu 5.2. i ogrzewać na płycie grzejnej $\mathrm{w}$ temperaturze około $150^{\circ} \mathrm{C}$ do prawie całkowitego odparowania kwasu azotowego(V). Po wystygnięciu roztworu dodać ponownie $2 \mathrm{ml}$ kwasu azotowego(V) wg punktu 5.2. i kroplę kwasu chlorowodorowego wg punktu 5.3. i ogrzewać na płycie grzejnej w temperaturze około $150{ }^{\circ} \mathrm{C}$ aż do uzyskania suchej pozostałości. Po ostygnięciu roztworu dodać po $5 \mathrm{ml} \mathrm{kwa-}$ su azotowego o stężeniu $1 \mathrm{~mol} / \mathrm{l}$ wg punktu 5.5. i pozostawić na $30 \mathrm{~min}$. Następnie całość przenieść ilościowo do kolby o pojemności $25 \mathrm{ml}$, przemyć pięcioma lub sześcioma porcjami kwasu azotowego(V) wg punktu 5.4. i uzupełnić do kreski kwasem azotowym(V) wg punktu 5.4. W taki sam sposób wykonać roztwór kontrolny z czystego filtra $\mathrm{z}$ pominięciem nanoszenia $100 \mu \mathrm{l}$ roztworu wzorcowego niklu wg punktu 5.6.

Należy przygotować trzy roztwory porównawcze przez odmierzenie do kolb o pojemności $25 \mathrm{ml}$ po $100 \mu \mathrm{l}$ roztworu wzorcowego niklu wg punktu 5.6. i $5 \mathrm{ml} \mathrm{kwasu} \mathrm{azotowego(V)} \mathrm{wg} \mathrm{punktu} \mathrm{5.5.}$ i uzupełnienie do kreski kwasem azotowym(V) wg punktu 5.4.

Wykonać trzykrotny pomiar absorbancji przygotowanych roztworów, przyjmując warunki pracy spektrometru wg Rozdziału 8. Do zerowania spektrometru używać kwasu azotowego(V) wg punktu 5.4. 
Współczynnik wydajności mineralizacji niklu $\left(w_{m}\right)$ obliczyć wg wzoru:

$$
w_{m}=\frac{C_{m}-C_{0}}{C_{p}},
$$

gdzie:

$$
\begin{aligned}
C_{m}- & \text { odczytane z krzywej stężenie niklu } \\
& \text { w roztworach do badania wydajności } \\
& \text { mineralizacji, w mikrogramach } \\
& \text { na mililitr; } \\
C_{0}- & \text { odczytane z krzywej stężenie niklu } \\
& \text { w roztworze kontrolnym, } \\
& \text { w mikrogramach na mililitr; } \\
C_{p}- & \text { odczytane z krzywej stężenie niklu } \\
& \text { w roztworach porównawczych, } \\
& \text { w mikrogramach na mililitr. }
\end{aligned}
$$

\section{Wykonanie oznaczenia}

Filtr wg punktu 6.3., na który pobrano próbkę powietrza, umieścić w zlewce, dodać $2 \mathrm{ml}$ kwasu azotowego(V) wg punktu 5.2. i ogrzewać na płycie grzejnej w temperaturze około $150{ }^{\circ} \mathrm{C}$ do prawie całkowitego odparowania kwasu azotowego(V). Po wystygnięciu roztworu dodać ponownie $2 \mathrm{ml}$ kwasu azotowego wg punktu 5.2. i kroplę kwasu chlorowodorowego wg punktu 5.3. i ogrzewać na płycie grzejnej w temperaturze około $150^{\circ} \mathrm{C}$ aż do uzyskania suchej pozostałości. Po ostygnięciu roztworu dodać po $5 \mathrm{ml}$ kwasu azotowego o stężeniu $1 \mathrm{~mol} / \mathrm{l} \mathrm{wg}$ punktu 5.5. i pozostawić na $30 \mathrm{~min}$. Następnie całość przenieść ilościowo do kolby o pojemności $25 \mathrm{ml}$, przemyć pięcioma lub sześcioma porcjami kwasu azotowego $(\mathrm{V})$ wg punktu 5.4. i uzupełnić do kreski kwasem azotowym(V) wg punktu 5.4. W taki sam sposób wykonać mineralizację czystego filtra wg punktu 6.3. w celu przygotowania roztworu do próby ślepej.

Wykonać trzykrotny pomiar absorbancji roztworu do badania oraz roztworu próby ślepej, pomiar należy wykonać w takich samych warunkach jak pomiary krzywej wzorcowej wg Rozdziału 9.

\section{Obliczanie wyniku oznaczenia}

Stężenie niklu i jego związków $(X)$ w badanym powietrzu należy obliczyć wg podanego wzoru, otrzymując jednostkę miligramów na metr sześcienny:

$$
X=\frac{\left(C-C_{0}\right) \cdot V_{1}}{V \cdot w_{m}} \cdot k,
$$

gdzie:

C - stężenie niklu w roztworze do badania, w mikrogramach na mililitr;

$C_{0}$ - stężenie niklu w roztworze do próby ślepej, w mikrogramach na mililitr;

$V_{1}$ - objętość roztworu do badania, w mililitrach $\left(V_{1}=25 \mathrm{ml}\right)$;

$V$ - objętość powietrza przepuszczanego przez filtr, w litrach;

$w_{m}-$ średnia wartość współczynnika wydajności mineralizacji;

$k$ - krotność rozcieńczenia roztworu do badania.
Adres do korespondencji/Contact details: mgr PAWEŁ WASILEWSKI e-mail: pawas@ciop.pl Centralny Instytut Ochrony Pracy Państwowy Instytut Badawczy 00-701 Warszawa, ul. Czerniakowska 16 POLAND 
